\title{
Index of Technical Terms
}

afrād (unique individuals) 72n98, 74n103, 76

a'läm/dalā'il al-nubuwwah (signs of prophecy) 38,60

al-amr al-ilāhì (the divine order) 90 al-'ayn al-bāținah (internal eye) 24

ataraxia (tranquillity) $13,56 \mathrm{n} 56$

awliyā' (saints) 24, 29, 91

bașīrah (spiritual insight) 4, 24, 26

burhān (demonstration) 5, 45-47, 63-66

diaphōnia (disagreement, dispute) 42, 51, 7778, 99-100

dawq (mystical experience) 4, 24, 29

dīn al-falāsifah (religion of the philosophers) 43-44, 99-100

epochē (suspension of judgment) $5,10,12,51$ $52,65 n 79$

ex nihilo (creation out of nothing) $63,66,69-$

74, 96, 100-101

habar; pl. ahbār (report, reports) 36-37, 62, 89

hadat, hâdit (innovation of the world) 63-64, 66, 70-71, 100-101

ilzām also ad hominem 12, 30n43, 90

isostheneia (equipollence of counterarguments) 10, 12, 49-51, 53, 56, 67, 90, 95, 100 istidlāl (inference) 24, 26, 28, 38

i'tiqād (core tenet of belief) 35, 71, 73-74 'iyān (direct sensory/eyewitness perception) 4, $24,37,45-46,54,56,58-59,64,66,73,89$ mofet (sign) 5, 45

mušāhadah (sensual and mystical experience) $4,24,26,58 \mathrm{n} 60,59$

mutašarri' (adherent of the Law) 53n50, 71-74, 96, 101

naql (oral tradition) 70, 71, 73n101, 89

nawāmīs (laws) 43

propeteia (rashness) 12, 67

qiyās (rational argumentation) 22, 82

qidam (eternity a parte ante of the world) 62-

$63,100-101$

šarā'ic (commandments) 21-22, 25, 44

sifät (attributes of God) 39n15, 54-60

skepsis (search, investigation, inquiry) 10, 19, 95

taqlīd (imitation) 4, 22, 28, 80-81

takāfu' al-adillah (equipollence/equivalent of counterarguments) 67-69

ta'rīh (chronology, history) 61-62, 71, 74n103, 89

tarğ̣̣̄ (assent, preponderance) 63, 64, 70

tașawwur (conceptualisation) 46n35

tașdīq (verification) 37, 46n35

tawātur (concurrent transmission) 4, 37-38, 56,

58-59, 60-61, 74n103, 89

topoi (modes) 13, 42

uṣūl al-fiqh (principles of the Law) 38, 61

mațbūc (naturally inclined) 22, 28, 29 
